\title{
ANALISIS KINERJA ALGORITMA PENGGALIAN PROSES UNTUK PEMODELAN PROSES BISNIS PERENCANAAN PRODUKSI DAN PENGADAAN MATERIAL DENGAN KRITERIA CONTROL-FLOW
}

\author{
Rachmadita Andreswari ${ }^{1)}$, Mahendrawathi ER ${ }^{2)}$ \\ ${ }^{1}$ Program Studi Sistem Informasi, Fakultas Rekayasa Industri, Telkom University \\ Jl. Telekomunikasi Terusan Buah Batu Bandung 40257 \\ ${ }^{2}$ Jurusan Sistem Informasi, Fakultas Teknologi Informasi, Institut Teknologi Sepuluh Nopember \\ Kampus Keputih, Sukolilo, Surabaya 60111 \\ Telp: (031) 5999944, Fax: (031) 5964965 \\ ${ }^{1}$ E-mail: andreswari@gmail.com
}

\begin{abstract}
This research conduct a performance comparison of four process mining algorithms namely Alpha++, Duplicate Task Genetics, Genetic and Heuristic Miner on two SAP business processes, i.e. production planning and materials management. First, the event logs of the two business processes are extracted from PT. XYZ. Then the event logs are processed by process mining application, called ProM. After the model processes are generated, evaluated using the conformance checking, $f$-score metrics, and evaluation of the ability to handle control-flow. Findings from the research shows that the best algorithm according to conformance checking in production planning is duplicate task genetics, while the heuristic miner is the best algorithm for materials management. Algorithm that has a good ability in handling control-flow is heuristic miner. Overall, it was also found that heuristic miner is able to handle control flow, gives high performance to model the business process and achieve it in a short running period.
\end{abstract}

\section{Abstrak}

Pada penelitian ini akan dilakukan perbandingan kinerja dari empat algoritma penggalian proses, yaitu alpha++, duplikat genetika, genetika dan heuristic miner pada dua proses bisnis SAP, yaitu production planning dan material management. Pertama, event log dari dua proses bisnis diekstraksi dari PT.XYZ. Kemudian event log diproses dengan aplikasi penggalian proses, yaitu ProM. Setelah dihasilkan model proses, dilakukan evaluasi menggunakan conformance checking, metrik F-score, dan evaluasi kemampuan dalam menangani control-flow. Hasil yang didapatkan dari penelitian ini menunjukkan bahwa algoritma terbaik dilihat dari analisis kinerja pada perencanaan produksi adalah algoritma duplikat genetika dan pada pengadaan material adalah adalah heuristic miner. Algoritma yang mempunyai kemampuan baik dalam menangani kriteria control-flow adalah heuristic miner. Secara umum dari penelitian tesis ini didapatkan kesimpulan bahwa algoritma heuristic miner mempunyai kinerja yang tinggi, kemampuan menangani control-flow yang baik dan waktu pemodelan yang singkat.

Kata Kunci : penggalian proses, algoritma, control-flow, SAP

\section{PENDAHULUAN}

Perkembangan teknologi informasi saat ini telah menjadi bagian selaras dari perkembangan aktivitas bisnis. Dalam menjalankan proses bisnis, sebuah perusahaan perlu melakukan peningkatan secara berkelanjutan untuk mendapatkan keuntungan dan memperoleh kepuasan pelanggan. Keseluruhan kebutuhan bisnis tersebut mendorong perusahaan untuk implementasi aplikasi Enterprise Resource Planning (ERP). Umumnya, perusahaan yang mengimplementasikan aplikasi ERP menganggap proses bisnis yang ada pada ERP merupakan kondisi ideal.
Padahal dalam kenyataannya sangat mungkin terjadi perbedaan antara proses bisnis yang didefinisikan dengan pelaksanaaannya. Untuk itu perlu dilakukan deteksi terhadap perbedaan proses bisnis dengan membuat model proses bisnis dari aplikasi ERP.

Penggalian proses merupakan salah satu cara yang digunakan untuk melakukan pencarian terhadap bagaimana suatu prosedur bekerja. Selain itu penggalian proses dapat digunakan untuk melakukan delta analysis, yaitu membandingkan proses aktual dengan proses yang telah didefinisikan sebelumnya sehingga memicu 
dilakukannya rekayasa ulang proses bisnis (Aalst, dkk, 2004). Kualitas dari hasil penggalian proses sangat bergantung pada sumber data yang dimasukkan. Event log (catatan kejadian) merupakan sumber data penggalian proses yang berupa kumpulan catatan aktivitas yang dilakukan seorang pengguna di dalam sistem atau aplikasi ERP. Saat ini, peneliti dari Universitas Teknologi Eindhoven telah mengembangkan aplikasi khusus untuk penggalian proses, yaitu ProM. Saat ini terdapat lebih dari 30 algoritma yang digunakan dalam aplikasi ProM. Pada implementasinya, algoritma yang dipakai bergantung pada pendekatan yang dipilih (Saravanan \& Rama, 2011).

Penelitian ini mengacu pada kriteria algoritma penggalian proses untuk control-flow atau menurut perspektif proses. Kriteria tersebut merupakan bagian penting yang harus dimiliki oleh algoritma pengalian proses dalam memodelkan proses bisnis. Menurut perspektif proses terdapat beberapa kemampuan yang harus dimiliki suatu algoritma, antara lain kemampuan untuk mendeteksi aktivitas tersembunyi (hidden task) HT), kejadian duplikat (duplicate task/DT), konstruksi pemilihan tak bebas (non-free-choice construct/NFC), perulangan (loops/L), mendeteksi kejadian yang terjadi bersama baik implisit maupun eksplisit (detecting implisit/explisit concurrency/C), kemampuan melakukan mining dan memanfaatkan atribut waktu (mining and exploting time/T), mengatasi gangguan (noise/ N) dan mengatasi ketidaklengkapan (incompleteness/IC) (Aalst, 2004). Dengan menggunakan kriteria tersebut, hanya terdapat beberapa algoritma yang diimplementasikan dalam ProM dan mampu menghasilkan grafik petri net yang memenuhi sebagian besar kriteria. Dikarenakan tidak ada algoritma yang memenuhi semua kriteria, maka pada penelitian ini ditetapkan ambang batas minimal empat kriteria terpenuhi. Tabel 1 menjelaskan tentang kemampuan algoritma dalam menyelesaikan permasalahan pada control flow. Pada tabel tersebut terdapat algoritma alpha++, duplicate task genetic algorithm, genetic algorithm (GA) dan heuristic miner.

Pada penelitian sebelumnya, telah dilakukan implementasi algoritma alpha++, heuristic miner, algoritma genetika (GA) dan algoritma duplikat genetika (DTGA) pada studi kasus tertentu. Penelitian pertama dilakukan oleh A.K.A Medeiros, et.al (2006) disebutkan bahwa GA dapat merepresentasikan non-free-choice dan invisible. Disebutkan pula dalam penelitian Medeiros (2006), bahwa algoritma DGA mampu mendeteksi kejadian duplikat namun memerlukan iterasi yang lebih panjang dibandingkan GA. Weijters, et al. melakukan penelitian tentang heuristic miner tahun 2006, yang menjelaskan tentang pembuatan model proses bisnis menggunakan algoritma heuristic miner. Namun penelitian ini masih menggunakan data tiruan dalam membuat event log, sehingga dimungkinkan terdapat perbedaan jika diaplikasikan pada proses nyata. Sedangkan pada penelitian oleh Lijie Wen, et.al (2007) dijelaskan tentang peningkatan kemampuan algoritma alpha menjadi alpha++ ditinjau dari kemampuan dalam mendeteksi konstruksi non-free-choice. Penelitian sejenis juga dilakukan oleh Chen Li, et al (2011), A. Rozinat, et. al (2007), A. Rozinat \& Aalst (2008), dan Philip Weber (2009). Dari penelitian tersebut belum ada yang menggunakan algoritma penggalian proses lebih dari satu modul ERP dan menggunakan real event $\log$.

Tabel 1. Tinjauan Algoritma Process Mining

\begin{tabular}{|c|c|c|c|c|c|c|c|c|c|c|}
\hline No & Algoritma & HT & DT & NFC & $\mathbf{L}$ & $\mathbf{C}$ & $\mathbf{T}$ & $\mathbf{N}$ & IC & Literatur \\
\hline 1 & Alpha++ & - & - & $\mathbf{v}$ & v & $\mathbf{v}$ & v & - & - & $\begin{array}{l}\text { "Mining Process Models with } \\
\text { Non-Free-Choice Constructs" } \\
\text { (Lijie Wen, et al, 2007) }\end{array}$ \\
\hline 2 & $\begin{array}{l}\text { Duplicate } \\
\text { Tasks GA }\end{array}$ & $\mathbf{v}$ & $\mathbf{v}$ & $\mathbf{v}$ & v & - & $\mathbf{v}$ & $\mathbf{v}$ & v & $\begin{array}{l}\text { "Genetic Process Mining" } \\
\text { (Medeiros, 2006) }\end{array}$ \\
\hline 3 & Genetic & $v$ & - & $\mathbf{v}$ & v & - & $\mathbf{v}$ & $\mathbf{v}$ & v & $\begin{array}{l}\text { "Genetic process mining: an } \\
\text { experimental evaluation" } \\
\text { (Medeiros, et.al., 2007) }\end{array}$ \\
\hline 4 & $\begin{array}{l}\text { Heuristic } \\
\text { miner }\end{array}$ & $\mathbf{v}$ & - & v & $v$ & - & v & $\mathbf{v}$ & $\mathbf{v}$ & $\begin{array}{l}\text { "Process Mining with the } \\
\text { HeuristicsMiner algorithm" } \\
\text { (Weijters, et.al., 2006) }\end{array}$ \\
\hline \multirow{3}{*}{\multicolumn{4}{|c|}{$\begin{array}{l}\text { HT }=\text { Hidden Task } \\
\text { DT }=\text { Duplicate Task } \\
\text { NFC }=\text { Non-Free-Choice }\end{array}$}} & \multirow{3}{*}{\multicolumn{6}{|c|}{$\begin{array}{l}\mathrm{L}=\text { Loops } \\
\mathrm{C}=\text { Concurrency } \\
\mathrm{T}=\text { Exploiting Time }\end{array}$}} & $\mathrm{N}=$ Noise \\
\hline & & & & & & & & & & $\mathrm{IC}=$ Incompleteness \\
\hline & & & & & & & & & & \\
\hline
\end{tabular}


Oleh karena itu masih diperlukan kajian yang lebih jauh mengenai kinerja dari teknik penggalian proses yang telah ada. Kajian tersebut terutama untuk menganalisis kinerja algoritma penggalian proses ditinjau dari karakteristik event log yang berbeda pada proses bisnis yang menggunakan aplikasi SAP. Sehingga diperlukan penelitian yang bertujuan untuk pemodelan proses bisnis dalam rangka mengetahui kinerja teknik penggalian proses menggunakan algoritma alpha++, algoritma heuristic miner, algoritma genetika dan algoritma duplikat genetika dengan membandingkan pada dua proses bisnis dalam modul Perencanaan Produksi dan Pengadaan Material. Untuk penelitian ini digunakan event log dari PT. XYZ, perusahaan manufaktur yang menerapkan SAP dengan proses bisnis utama adalah pengelolaan produksi dan pengadaan material. Kedepan, hasil dari penelitian ini dapat dijadikan sebagai rujukan dalam menentukan algoritma yang sesuai untuk suatu bisnis proses secara spesifik.

\section{METODOLOGI}

Metodologi yang digunakan untuk menjalankan penelitian ini dimulai dari penggalian proses, telaah algoritma yang digunakan untuk penggalian proses serta SAP sebagai penyedia event log dan evaluasi pemodelan proses bisnis.

\subsection{Penggalian Proses}

Menurut Aalst, dkk (2004) penggalian proses merupakan suatu metode untuk melakukan penyaringan deskripsi proses yang terstruktur dari sekumpulan eksekusi nyata dari perusahaan. Terdapat tiga tipe dasar metode penggalian proses dalam kaitannya dengan input dan output, yaitu; (1) penemuan atau discovery, yang menghasilkan model tanpa menggunakan informasi apriori, (2) kesesuaian atau conformance, yang membandingkan model proses yang telah ada dengan event log (catatan kejadian) pada proses yang sama, dan (3) peningkatan atau enhancement, yang memperbaiki model proses yang telah ada menggunakan informasi tentang proses aktual yang ada pada catatan kejadian (Aalst, dkk, 2012).

Menurut Aalst (2012) setiap event log kemungkinan mempunyai karakteristik yang berbeda, beberapa event log mungkin berukuran sangat besar sehingga sulit untuk ditangani, disisi lain event log yang terlalu kecil tidak mempunyai data yang cukup untuk menghasilkan kesimpulan yang reliabel. Oleh karena itu, karakteristik event log yang berbeda dimungkinkan akan membutuhkan penanganan yang berbeda.

\subsection{Algoritma Penggalian Proses}

Terdapat relasi yang kuat antara algoritma penggalian dan jenis masalah yang dapat ditangani dengan sukses oleh algoritma tersebut (Aalst \& Weijters, 2004). Oleh karena itu diperlukan karakterisasi algoritma penggalian, dimulai dengan masalah yang dapat diselesaikan dengan sukses oleh algoritma (misalnya mengatasi noise, catatan tidak lengkap, penggunaan waktu, duplikasi aktivitas, konstruksi non-free-choice, loop, perspektif penggalian berbeda, visualisasi hasil penggalian, dll).

Hampir tidak mungkin untuk menggunakan teknik penggalian data secara langsung untuk penggalian proses (Aalst \& Weijters, 2004). Ini berarti hampir semua teknik penggalian proses mempunyai properti yang sangat spesifik. Banyak karakteristik yang relevan untuk algoritma penggalian data juga relevan untuk penggalian proses. Misalnya, bias induktif, dimensi lokalglobal, kompleksitas komputasi, kebutuhan memori, dll)

\subsection{Perangkat Lunak SAP}

Pada perangkat lunak SAP, modul PP dan modul MM merupakan bagian yang berperan dalam rantai pasok perusahaan. Production planning merupakan modul di dalam SAP yang bertugas untuk melakukan perencanaan produksi, dan proses manufakturnya (Wagner \& Weidner, 2009). Proses perencanaan produksi bergantung pada strategi perusahaan, yaitu make-to-stock (MTS) atau make-to-order (MTO). Proses perencanaan produksi merupakan proses umum dan termasuk salah satu elemen inti di dalam perusahaan yang di dalamnya terdapat beberapa proses bisnis. Material management merupakan modul yang bertugas menangani pengadaan material (Piessens, 2011). Proses ini adalah proses umum dan termasuk salah satu elemen inti di dalam perusahaan.

\subsection{Evaluasi Pemodelan Proses Bisnis}

Menurut A.Rozinat \& Aalst (2009) ada empat dimensi evaluasi model proses yang saat ini sering dipakai yaitu fitness, precision, generalization dan structure.

\section{a. Fitness}

Nilai fitness berada dalam range $0-1$, dan bisa dihitung dengan menggunakan rumus (1)

$$
\begin{aligned}
& \mathrm{f}=\frac{1}{2}\left(1-\frac{\sum_{\mathrm{i}=1}^{\mathrm{k}} \mathrm{n} i \mathrm{~m} i}{\sum_{\mathrm{i}=1}^{\mathrm{k}} \mathrm{n} i c i}\right)+ \\
& \frac{1}{2}\left(1-\frac{\sum_{\mathrm{i}=1}^{\mathrm{k}} \mathrm{n} i \mathrm{r} i}{\sum_{\mathrm{i}=1}^{\mathrm{k}} \mathrm{n} i \mathrm{p} i}\right)
\end{aligned}
$$


Dimana $k$ adalah jumlah trace yang berbeda. Untuk setiap log trace $i(1 \leq i \leq k)$, n $i$ adalah jumlah instance proses dari trace $I$, $\mathrm{mi}$ adalah jumlah token yang hilang dari trace $I$, ci adalah jumlah token yang dikonsumsi dari trace I, ri adalah jumlah token yang tersisa dari trace $\mathrm{I}$, dan $\mathrm{P} i$ adalah jumlah token yang diproduksi dari trace $i$.

b. Precision

Nilai precision berada dalam range $0-1$, dan bisa dihitung dengan menggunakan rumus "Advanced Behavioral Appropriateness"(2) berikut ini:

$$
\mathrm{a}^{\prime} \mathrm{B}=\left(\frac{\left|\mathrm{S}_{\mathrm{F}}^{\mathrm{l}} \cap \mathrm{S}_{\mathrm{F}}^{\mathrm{m}}\right|}{2 \cdot\left|\mathrm{S}_{\mathrm{F}}^{\mathrm{m}}\right|}+\frac{\left|\mathrm{S}_{\mathrm{P}}^{\mathrm{l}} \cap \mathrm{S}_{\mathrm{P}}^{\mathrm{m}}\right|}{2 . \mid \mathrm{S}_{\mathrm{P}}^{\mathrm{m}_{1}}}\right)
$$

Dimana $\mathrm{S}_{\mathrm{F}}^{\mathrm{m}}$ adalah relasi "Sometimes follows" untuk model proses, $\mathrm{S}_{\mathrm{P}}^{\mathrm{m}}$ adalah relasi "Sometimes precedes" untuk model proses, $\mathrm{S}_{\mathrm{F}}^{\mathrm{l}}$ adalah relasi "Sometimes follows" untuk event log, dan $\mathrm{S}_{\mathrm{P}}^{\mathrm{l}}$ adalah relasi "Sometimes precedes" untuk event $\log$.

c. Generalization

Dimensi evaluasi ini menunjukkan bentuk model secara umum. Dimensi ini berlawanan dengan dimensi precision, lebih fleksibel terhadap kemungkinan model yang dihasilkan dari data catatan kejadian lain. Walaupun demikian, bentuk model tidak terlalu bagus, karena tidak mempertimbangkan relasi antara proses.

\section{d. $\quad$ Structure}

Struktural berkaitan dengan perspektif control flow dan seringkali ada beberapa cara sintaksis untuk mengekspresikan perilaku dalam proses model. Nilai strutural dapat dihitung dengan rumus (3) berikut ini:

$a^{\prime} S=\frac{|T|-\left(\left|T_{D A}\right|+\left|T_{I R}\right|\right)}{|T|}$

Dimana T adalah transisi dalam model Petri net, $\mathrm{T}_{\mathrm{DA}}$ adalah kumpulan dari alternatif duplikat task dan $\mathrm{T}_{\mathrm{IR}}$ adalah kumpulan dari task tak terlihat yang redundan.

\section{e. $\quad$-score}

Dimensi ini digunakan untuk melakukan kombinasi perhitungan nilai fitness dan presisi. Weerdt (2012) menyebutkan bahwa salah satu matriks dalam nilai presisi adalah a'B (advanced behavioral appropriateness) dan salah satu matriks recall yang cukup dikenal adalah fitness. Rumus F-score dapat dilihat seperti dibawah ini.
$\mathrm{F}_{\beta}=\frac{(1+\beta)^{2} \times \text { precision } \times \text { recall }}{\beta^{2} \times(\text { precision }+ \text { recall })}$

$\beta$ adalah faktor bobot yang mempengaruhi tingkat kepentingan relatif antara presisi dan recall

Metodologi yang digunakan untuk menyelesaikan permasalahan pada penelitian ini antara lain, studi literatur, pengumpulan data, ekstraksi data, standarisasi catatan kejadian, pemodelan proses bisnis dan analisis kinerja algoritma. Studi Literatur dilakukan dengan mengkaji literatur penunjang, perbandingan algoritma dan studi kasus. Selanjutnya pengumpulan data perusahaan yang menerapkan sistem ERP serta melakukan wawancara alur proses bisnis, implementasi ERP, dan permasalahan yang terjadi di perusahaan. Kemudian menentukan data yang diekstraksi, atribut, dan jumlah data. Pada pemodelan proses bisnis menggunakan algoritma penggalian proses, diperlukan ekstensi yang sesuai dengan input yang diperbolehkan, yaitu *.mxml. Standardisasi ini dapat dilakukan dengan aplikasi Disco.

Setelah event log terbentuk, langkah selanjutnya adalah melakukan penggalian proses dengan aplikasi ProM. Hasil yang Melalui penelitian ini didapatkan hasil bahwa algoritma terbaik dilihat dari analisis kinerja pada perencanaan produksi adalah algoritma duplikat genetika dan pada pengadaan material adalah adalah heuristic miner. Algoritma yang mempunyai kemampuan baik dalam menangani kriteria control-flow adalah heuristic miner. Secara umum dari penelitian tesis ini didapatkan kesimpulan bahwa algoritma heuristic miner mempunyai kinerja yang tinggi, kemampuan menangani controlflow yang baik dan waktu pemodelan yang singkat. didapatkan dari penggalian proses adalah grafik model proses bisnis dalam bentuk petrinet. Pemodelan dilakukan pada modul Perencanaan Produksi dan Pengadaan Material dengan menggunakan 4 algoritma.

Tahap terakhir pada metodologi adalah analisis kinerja, yang mencakup analisis kinerja algoritma menurut perhitungan fitness, precision, generalization dan structure, analisis karakteristik control-flow dan analisis waktu running.

\subsection{Deskripsi Proses Bisnis}

Pada bagian ini akan dijelaskan mengenai proses bisnis dari masing-masing event log. Terdapat dua proses bisnis, yaitu Perencanaan Produksi, dan Pengadaan Material. PT. XYZ Indonesia merupakan anak perusahaan PT. XYZ Internasional yang memproduksi shoe dan up- 
per shoe. PT. XYZ telah mengimplementasikan software ERP yaitu SAP untuk membantu menjalankan proses bisnisnya. Proses bisnis utama PT. XYZ adalah pengelolaan produksi dan pengadaan material (Utami, 2013). Pada bagian ini akan dijelaskan mengenai proses bisnis dari masing-masing event log.

\section{a. Perencanaan Produksi}

Pada proses bisnis perencanaan produksi terdapat 7 aktivitas, antara lain run MRP, plan order, change plan order date, change line, convert on, issued production order, dan start production. Run MRP merupakan aktivitas yang dilakukan untuk menghitung kebutuhan material Plan Order merupakan rencana produksi yang dihasilkan dari aktivitas Run MRP. Change Plan Order Date atau Reschedule, adalah aktivitas melakukan perubahan jadwal produksi. Change Line merupakan aktivitas untuk merubah line produksi pada plan order. Convert On, aktivitas untuk merubah status plan order menjadi production order dengan anggapan plan order tersebut siap diproduksi. Issued Production Order, merupaan aktivitas fiksasi bahwa plan order sudah benar-benar siap diproduksi. Start Production, merupakan aktivitas untuk memulai proses produksi.

\section{b. Pengadaan Material}

Proses bisnis pengadaan material terdiri dari beberapa proses, antara lain run $M R P$, planned order, status material A, status material B, status material L, status material $C$, material issued dan start production. Run MRP (Materials Require-ment Planning) merupakan aktivitas yang dilakukan pada perangkat lunak SAP. Planned Order merupakan rencana produksi yang dihasilkan dari aktivitas Run MRP. Status Material merupakan aktivitas penentuan status dari sebuah komponen material. Status A, material tersebut saat ini tidak tersedia di warehouse sehingga bagian perencanaan produksi membuat rekuisisi kepada departemen pembelian untuk mengadakan material. Status B, material sudah dipesan dari vendor tetapi belum ada konfirmasi kepastian atau komitmen kapan akan dikirimkan. Status L, material sudah dipesan dari vendor dan saat ini sedang dalam proses pengiriman. Status C, material tersebut saat ini terdapat stok, dan siap digunakan untuk proses produksi. Materials Issued merupakan aktivitas yang hanya bisa dilakukan apabila status sebuah material adalah C. Start Production merupakan aktivitas terakhir dalam rangkaian proses perencanaan produksi

\section{c. Ekstraksi Data}

Ekstraksi data dilakukan dari aplikasi SAP pada proses bisnis perencanaan produksi dan pengadaan material. Setelah data didapatkan dalam ekstensi *.csv, *.xls atau *.xlsx, kemudian data $\log$ dikonversi ke dalam *.mxml melalui aplikasi Disco. Minimum atribut yang digunakan antara lain id case, activity, dan timestamp. Sehingga dari ekstraksi data didapatkan dua event log, yaitu perencanaan produksi dan pengadaan material.

\section{d. Pembentukan Model}

Dalam membentuk model, dilakukan dengan 3 tahap, yaitu input pemodelan proses bisnis, proses pemodelan proses bisnis, dan output pemodelan proses bisnis. Pada tahap input, berasal dari event log yang distandardisasi melalui aplikasi Disco yang telah disimpan dalam ekstensi *.mxml. Selanjutnya, tahap proses dilakukan dengan memasukkan event log ke dalam aplikasi ProM dan menjalankannya dengan salah satu algoritma penggalian proses. Setelah itu akan terbentu grafik hasil pemodelan. Jika hasilnya sudah dalam bentuk petri net, maka dapat dilakukan pengukuran conformance checking melalui ProM. Tetapi jika masih dalam bentuk selain petri net, harus dilakukan konversi terlebih dahulu. Output yang dihasilkan pada penggalian proses ini berupa model proses dalam bentuk petri net seperti yang terlihat pada Gambar 1.

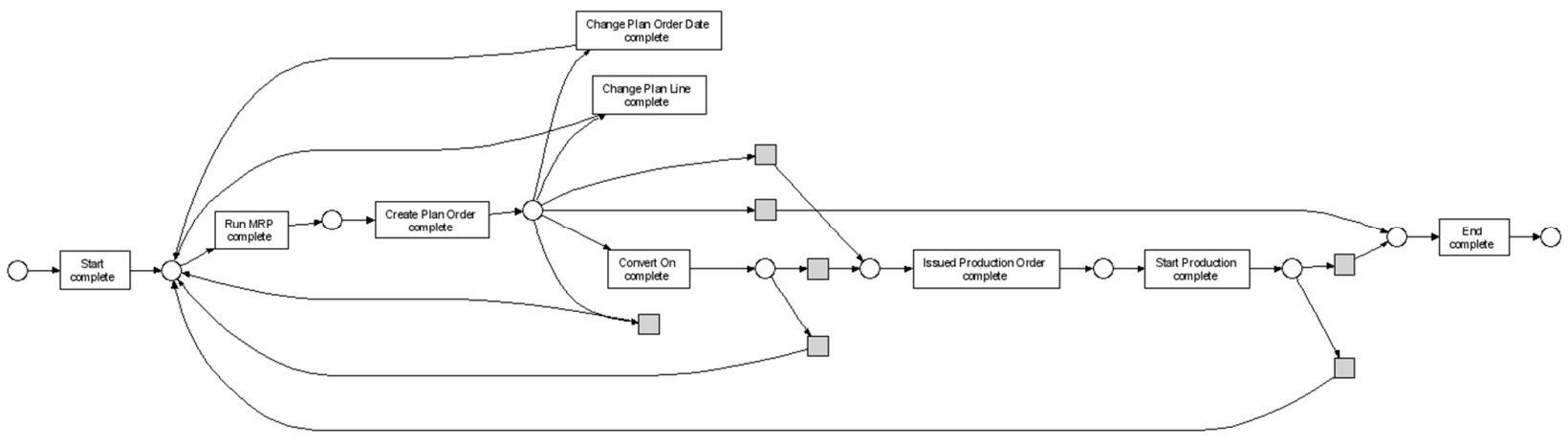

Gambar 1. Model Proses Perencanaan Produksi C menggunakan Algoritma Heuristic Miner 
Andreswari, dkk., Analisis Kinerja Algoritma Penggalian Proses untuk Pemodelan Proses Bisnis..

Gambar 1 merupakan salah satu contoh hasil pemodelan proses pada perencanaan produksi menggunakan algoritma heuristic miner.

e. Analisis Karakteristik Control-Flow Untuk melakukan analisis karakteristik model proses dari kedua proses bisnis, pertama yang perlu dilakukan adalah memetakan skenario yang mungkin dari tiap event log. Langkah selanjutnya setelah model proses terbentuk adalah melakukan analisis model terhadap kriteria control-flow. Masing-masing model pada proses bisnis perencanaan produksi maupun pengadaan material yang dimodelkan dengan keempat algoritma akan dianalisis menurut kemampuan menangani hidden task, duplicate task, nonfree-choice, loops, implisit/ explicit concurrency, mining \& exploiting time, noise dan incompleteness. Tabel 2 menyajikan hasil analisis control-flow pada proses perencanaan produksi dan pengadaan material.
Pada Tabel 2, penilaian nol dan satu menunjukkan kemampuan algoritma dalam menangani permasalahan control-flow. Dimana jika nilainya nol, berarti algoritma tersebut tidak mampu menangani control-flow, sebaliknya jika 1 maka algoritma mampu menangani control-flow.

\section{f. Pengukuran Model}

Dalam melakukan pengukuran model, maka perlu dilakukan perhitungan kinerja. Dimensi pengukuran yang digunakan antara lain, fitness, presisi dan struktural. Hal ini sesuai dengan teori pada paper "Conformance Checking of Processes Based on Monitoring Real Behavior". Tabel 3 adalah hasil rekapitulasi pengukuran kinerja penggalian proses. Selanjutnya dilakukan perhitungan F-score yang mempertimbangkan nilai precision dan recall. Tabel 4 merupakan hasil pengukuran F-score dari proses bisnis perencanaan produksi dan pengadaan material.

Tabel 2. Rekapitulasi Hasil Analisis Control Flow pada Proses Bisnis C

\begin{tabular}{ccccccccc}
\hline $\begin{array}{c}\text { Kriteria Control } \\
\text { Flow }\end{array}$ & \multicolumn{4}{c}{ Perencanaan Produksi } & \multicolumn{3}{c}{ Pengadaan Material } \\
\cline { 2 - 9 } & GA & HM & a ++ & DTGA & GA & HM & a ++ & DTGA \\
\hline$H T$ & 1 & 1 & $\mathbf{0}$ & 1 & 1 & 1 & $\mathbf{0}$ & 1 \\
$D T$ & 1 & 1 & 1 & 1 & 1 & 1 & 1 & 1 \\
$N F C$ & 1 & 1 & 1 & 1 & 1 & 1 & 1 & 1 \\
$L$ & 1 & 1 & 1 & 1 & 1 & 1 & $\mathbf{0}$ & 1 \\
$I C$ & 1 & 1 & $\mathbf{0}$ & $\mathbf{0}$ & $\mathbf{0}$ & 1 & $\mathbf{0}$ & $\mathbf{0}$ \\
$T$ & 1 & 1 & 1 & 1 & 1 & 1 & 1 & 1 \\
$N$ & 1 & 1 & $\mathbf{0}$ & 1 & $\mathbf{0}$ & $\mathbf{0}$ & $\mathbf{0}$ & $\mathbf{0}$ \\
$I C$ & 1 & 1 & 1 & 1 & 1 & 1 & $\mathbf{0}$ & 1 \\
\hline Jumlah & $\mathbf{8}$ & $\mathbf{8}$ & $\mathbf{5}$ & $\mathbf{7}$ & $\mathbf{6}$ & $\mathbf{7}$ & $\mathbf{3}$ & $\mathbf{6}$ \\
\hline
\end{tabular}

Tabel 3.Rekapitulasi Pengukuran Kinerja Proses Bisnis

\begin{tabular}{|c|c|c|c|c|c|c|c|c|}
\hline \multirow{2}{*}{ Algoritma } & \multicolumn{3}{|c|}{ Perencanaan Produksi } & \multirow{2}{*}{ Time } & \multicolumn{3}{|c|}{ Pengadaan Material } & \multirow{2}{*}{ Time } \\
\hline & Fitness & Presisi & Struktural & & Fitness & Presisi & Struktural & \\
\hline GA & 1 & 0.473 & 1 & $\begin{array}{c}5.38 .22: \\
560\end{array}$ & 0.9553 & 0.410 & 1 & $\begin{array}{c}4.4 .32 \\
983\end{array}$ \\
\hline HM & 1 & 0.473 & 1 & $0.0 .2: 200$ & 0.9447 & 0.415 & 1 & $\begin{array}{c}0.0 .1: \\
297\end{array}$ \\
\hline Alpha++ & 0.949 & 0.427 & 1 & 0.0.0: 891 & 0.718 & 0.230 & 1 & $\begin{array}{c}0.0 .0: \\
826\end{array}$ \\
\hline DTGA & 0.952 & 0.543 & 1 & 5.15.18: 19 & 0.9553 & 0.410 & 1 & $\begin{array}{l}4.17 .2 \\
3: 554\end{array}$ \\
\hline
\end{tabular}

Tabel 4 Hasil Perhitungan F-score

\begin{tabular}{ccc}
\hline Algoritma & $\begin{array}{c}\text { Perencanaan } \\
\text { Produksi }\end{array}$ & $\begin{array}{c}\text { Pengadaan } \\
\text { Material }\end{array}$ \\
\hline Genetika & 0.723 & 0.645 \\
HM & 0.723 & $\mathbf{0 . 6 4 9}$ \\
Alpha++ & 0.663 & 0.392 \\
DTGA & $\mathbf{0 . 7 7 8}$ & 0.645 \\
\hline
\end{tabular}

\section{HASIL dan PEMBAHASAN}

Analisis ini dilakukan untuk mengetahui pengaruh penggunaan algoritma terhadap hasil pengukuran kinerja menurut Conformance Checking dan F-score. 


\subsection{Analisis menurut Karakteristik Control- Flow}

Analisis ini digunakan untuk melihat pengaruh kesesuaian karakteristik model proses pada implementasi penggunaan algoritma penggalian proses. Berikut ini karakteristik dari event log perencanaan produksi dan pengadaan material

a. Karakteristik proses bisnis Perencanaan Produksi

Terdapat hidden task, tidak terdapat kejadian duplikat, tidak terdapat non-free-choice, terdapat loops, tidak terdapat implicit/explicit concurrency, memungkinkan memberikan informasi waktu (terdapat timestamp), tidak terdapat noise dan tidak terdapat incompleteness.

b. Karakteristik proses bisnis Pengadaan Material

Terdapat hidden task, tidak terdapat kejadian duplikat, tidak terdapat non-free-choice, terdapat loops, tidak terdapat implicit/explicit concurrency, memungkinkan memberikan informasi waktu (terdapat timestamp), terdapat noise dan tidak terdapat incompleteness.

c. Perbedaan karakteristik dari kedua proses bisnis terletak pada jumlah loops dan jumlah hidden task.

Dimana pengadaan material cenderung mempunyai lebih banyak loops daripada perencanaan produksi, dan perencanaan produksi cenderung mempunyai lebih banyak hidden task daripada pengadaan material. Keberadaan loops tersebut pada aktivitas status material A, B, L, C maupun plan order. Selain itu pada perencanaan produksi tidak terdapat noise, sedangkan pada pengadaan material terdapat noise.

Analisis berikut ini dilakukan untuk mengetahui kemampuan masing-masing algoritma dalam menangani karakteristik model proses bisnis perencanaan produksi dan pengadaan material.

\section{a. Algoritma Alpha++}

Pada perencanaan produksi, algoritma alpha++ tidak mampu menangani hidden task, implicit/ explicit concurrency dan noise sedangkan pada pengadaan material tidak mampu menangani hidden task, loops, implicit/explicit concurrency, noise dan incompleteness.

b. Algoritma Duplicate Task Genetika Pada perencanaan produksi, algoritma duplicate genetika tidak mampu menangani implicit/explicit concurrency, sedangkan pada pengadaan material tidak mampu menangani implicit/explicit concurrency dan noise.

\section{c. Algoritma Genetika}

Pada perencanaan produksi, algoritma genetika mampu menangani keseluruhan permasalahan control-flow, sedangkan pada pengadaan material tidak mampu menangani implicit/explicit concurrency dan noise.

\section{d. Algoritma Heuristic Miner}

Pada perencanaan produksi, algoritma heuristic miner mampu menangani keseluruhan permasalahan control-flow, sedangkan pada pengadaan material tidak mampu menangani noise.

\subsection{Analisis menurut Kinerja}

Pada perencanaan produksi, nilai fitness yang paling baik didapatkan dari pemodelan menggunakan algoritma Genetika, dan Heuristic Miner yaitu dengan nilai fitness 1 , sedangkan pada pengadaan material fitness paling baik didapatkan dari pemodelan menggunakan algoritma Genetika dan Duplikat Genetika, yaitu dengan nilai fitness 0.955 . Nilai fitness menggunakan algoritma alpha++ selalu lebih rendah jika dibandingkan dengan ketiga algoritma lain pada kedua proses bisnis. Secara keseluruhan, nilai fitness untuk proses bisnis perencanaan produksi mempunyai nilai yang lebih baik jika dibandingkan dengan pengadaan material.

Pada perencanaan produksi, nilai presisi paling baik didapatkan dari pemodelan dengan menggunakan algoritma duplikat genetika, yaitu 0.543. Sedangkan pada pengadaan material, nilai presisi paling baik didapatkan dari pemodelan dengan menggunakan algoritma Heuristic Miner, yaitu 0.415. Nilai presisi untuk pemodelan dengan algoritma alpha++ selalu lebih rendah jika dibandingkan dengan ketiga algoritma lain pada kedua proses bisnis. Secara keseluruhan, nilai presisi untuk proses bisnis perencanaan produksi mempunyai nilai yang lebih baik jika dibandingkan dengan pengadaan material.

Dari hasil perhitungan nilai struktural untuk kedua proses bisnis didapatkan hasil yang sama, yaitu 1. Hal ini dikarenakan semua event log yang dimodelkan dengan algoritma alpha++, duplikat genetika, genetika dan heuristic miner tidak terdapat redundan invisible task dan duplicate alternative. Nilai struktural mempertimbangkan jumlah transisi, jumlah redundan invisible task (hidden task) dan duplicate task. Hasil analisis F-score, yang merupakan gabungan dari fitness dan presisi, didapatkan hasil bahwa algoritma yang mempunyai nilai F-score terbaik pada perencanaan produksi adalah Duplikat Genetika. Algoritma yang mempunyai nilai F-score terbaik pada pengadaan material adalah Heuristic Miner. 


\subsection{Analisis menurut Waktu Eksekusi}

Dari tabel 5 dapat diketahui bahwa rata-rata waktu running paling pendek didapatkan dari pemodelan menggunakan algoritma alpha++, diikuti terpendek kedua yaitu algoritma heuristic miner. Waktu running paling lama didapatkan dari pemodelan menggunakan algoritma genetika.

Tabel 5 Waktu Running Pemodelan Proses Bisnis

\begin{tabular}{lll}
\hline Algoritma & $\begin{array}{c}\text { Perencanaan } \\
\text { Produksi }\end{array}$ & $\begin{array}{c}\text { Pengadaan } \\
\text { Material }\end{array}$ \\
\hline GA & $5.38 .22: 560$ & $4.4 .32: 983$ \\
HM & $0.0 .2: 200$ & $0.0 .1: 297$ \\
Alpha++ & $0.0 .0: 891$ & $0.0 .0: 826$ \\
DTGA & $5.15 .18: 19$ & $4.17 .23: 554$ \\
\hline
\end{tabular}

\section{SIMPULAN dan SARAN}

Menurut hasil analisis kriteria control-flow yang dihasilkan pada pemodelan proses, didapatkan bahwa algoritma yang paling mampu menangani kriteria control-flow pada perencanaan produksi adalah algoritma heuristic miner dan algoritma genetika. Sedangkan algoritma yang mampu menangani kriteria control-flow pada pengadaan material adalah heuristic miner. Proses bisnis perencanaan produksi cenderung mempunyai lebih banyak aktivitas hidden task daripada pengadaan material. Sedangkan proses bisnis pengadaan material cenderung terdapat noise dan mempunyai lebih banyak aktivitas perulangan (loops) dibandingkan proses bisnis perencanaan produksi.

Menurut hasil perhitungan F-score, yaitu gabungan antara nilai fitness dan presisi, didapatkan bahwa pada event log perencanaan produksi dengan karakteristik lebih banyak hidden task dapat ditangani dengan baik menggunakan algoritma duplikat genetika. Sedangkan pada event log pengadaan material dengan karakteristik lebih banyak loops dan terdapat noise dapat ditangani dengan baik menggunakan algoritma heuristic miner. Secara umum, kemampuan dalam menangani kriteria control-flow berpengaruh terhadap hasil perhitungan kinerja, baik fitness, presisi maupun struktural. Semakin suatu algoritma mampu menangani kriteria controlflow pada model, algoritma tersebut semakin mempunyai kinerja yang lebih baik. Berdasarkan kemampuan menangani kriteria controlflow, perhitungan kinerja yang relatif tinggi dan waktu eksekusi yang cepat, didapatkan kesimpulan bahwa algoritma heuristic miner merupakan algoritma terbaik untuk proses bisnis perencanaan produksi dan pengadaan material.

Saran bagi pihak yang akan menerapkan algoritma penggalian proses pada perbandingan kiner- ja proses bisnis, dalam melakukan analisis perbandingan kinerja dipengaruhi oleh variasi skenario dan frekuensi kasus. Agar meningkatkan kinerja, sebaiknya skenario yang ada mempunyai frekuensi tinggi. Penggunaan algoritma penggalian proses sebaiknya sesuai dengan tujuan, sumber daya dan waktu yang tersedia, agar didapatkan hasil yang optimal.

\section{DAFTAR RUJUKAN}

Aalst, W., Weijters, A., \& Maruste, L. (2004). Workflow Mining Discovering Process Models from Event Logs. IEEE Transactions on Knowledge and Data Engineering, 16 (9), 1128-1142

Aalst, W., \& et. al. (2012). Process Mining Manifesto. BPM 2011 Workshops Proceedings (pp. 169-194). Springer-Verlag.

Li, C., \& et. al. (2011). Mining Business Process Variants: Challenges, Scenarios, Algorithms. Data \& Knowledge Engineering, 409-434.

Lijie Wen, \& et. al. (2007). Mining Process Models with Non-Free-Choice Constructs. Eindhoven: Technische Universiteit Eindhoven.

Medeiros, A., \& et. al. (2006). Genetic Process Mining. Eindhoven: Technische Universiteit Eindhoven.

Medeiros, A., \& et. al. (2006). Genetic Process Mining: an Experimental Evaluation. Journal of DataMining and Knowledge Discovery.

Piessens, D. (2011). Event Log Extraction from SAP ECC 6.0. Technische Universiteit Eindhoven.

Rozinat, A., \& et. al. (2007). Towards an Evaluation Framework for Process Mining Algorithms.

Rozinat, A., \& Aalst, W. (2009). Conformance Checking of Processes Based on Monitoring Real Behavior. Eindhoven: Technische Universiteit Eindhoven, 1-44.

Saravanan, M., \& Rama, S. (2011). Aplication of Mining Algorithms using ProM and Weka Tools. International Journal of Computer Science and Technology, 331-337.

Wagner, B., \& Weidner, S. (2009). SAP Production Planning (PP) and Execution Module for University Alliance.

Weber, P. (2009). A framework for the Comparison of Process Mining Algorithms. Birmingham: School of Computer Science University of Birmingham.

Weijters, A., \& et. al. (2006). Process Mining with the Heuristic Miner Algorithm. BETA Working Paper Series, 1-34. 